\title{
Level of Adherence and Its Determinants of Prolanis Attendance in Type 2 Diabetes Mellitus Participants at Five BPJS Primary Health Care in Bekasi 2016
}

\author{
* Ledy Visna Asfiani, ** Yaslis Ilyas \\ * Faculty of Public Health Universitas Indonesia \\ ** Department Health Administration and Policy, Faculty of Public Health Universitas Indonesia \\ Email: ledyasfiani04@gmail.com
}

\begin{abstract}
The continuity of the participation in Prolanis is one of the primary health care services indicators of commitment, so finding out the level of adherence and the factors influencing it is very important. The aim of the study is to investigate the adherence level of Prolanis participanst and its determinants in type 2 diabetes patients at five BPJS primary health care in Bekasi. This is a cross sectional study, using questionnare to 220 participants with type 2 diabetes by simple random sampling method proportionally. Adherence level of the participants is 3.59 out of 6 times. Length of illness, perceived benefits, perceived barriers and the implementation of the program guidelines are correlated with the adherence level and the dominant factor is perceived barriers. Factors in individual and provider can be used as evaluation tools for the primary health care in facilitating the participants' needs so that it would increase the level of adherence.
\end{abstract}

Keywords: Adherence level, Prolanis' participant, type 2 diabetes, determinants.

Abstrak. Kontinuitas peserta untuk mengikuti Prolanis merupakan salah satu indikator komitmen pelayanan di FKTP, sehingga mengetahui tingkat kepatuhan dan faktor yang mempengaruhinya menjadi hal yang penting. Tujuan dari penelitian ini adalah untuk menganalisis tingkat kepatuhan mengikuti Prolanis dan determinannya pada pasien DM tipe 2 yang mengikuti Prolanis di lima FKTP BPJS Bekasi. Penelitian ini menggunakan disain cross sectional, pengumpulan data melalui pengisian kuesioner pada 220 peserta Prolanis dengan DM tipe 2 di lima FKTP BPJS Bekasi dan diambil dengan acak sederhana secara proporsional sesuai dengan jumlah peserta di tiap FKTP. Hasil penelitian menunjukkan tingkat kepatuhan peserta Prolanis dengan DM tipe 2 di lima FKTP tersebut adalah 3.59 kali dari total kepatuhan sebanyak 6 kali. Lama menderita sakit, persepsi manfaat, persepsi penghalang dan pelaksanaan pedoman program berhubungan dengan tingkat kepatuhan peserta. Persepsi penghalang merupakan faktor dominan yang berhubungan dengan tingkat kepatuhan peserta. Terdapat interaksi antara variabel persepsi manfaat dan persepsi penghalang yang secara signifikan berhubungan dengan tingkat kepatuhan pasien DM tipe 2 yang mengikuti Prolanis. Faktor pada individu dan provider tersebut dapat dijadikan sebagai bahan telaah bagi FKTP dalam memfasilitasi kebutuhan peserta sehingga dapat meningkatkan tingkat kepatuhan untuk mengikuti Prolanis.

Kata kunci: Tingkat kepatuhan, Prolanis, DM tipe 2, determinan

\section{INTRODUCTION}

Diabetes Mellitus is a chronic disease which affects 415 million people and causes the deaths of 5 million people worldwide. The magnitude of the problem caused by diabetes mellitus is that in every 7 minutes, a person dies because of this disease. Medical expenses of diabetes mellitus patients worldwide spend around 673 billion USD per year and this number will continue to increase over time (International Diabetes Federation, 2015). Based on statistics from the International Diabetes Federation (IDF), Indonesia is among the top ten countries with the highest prevalence of diabetes mellitus as Indonesia is the seventh rank, with the total number of cases in 2015 are 10 million. It is estimated that the number of people with diabetes mellitus in Indonesia will increase to 16.2 million in the year 2035 (International Diabetes Federation, 2015). Diabetes mellitus disease requires comprehensive and integrated services. There are three interrelated factors which determine the success of type 2 diabetes management i.e. health care facility, the patient itself and health care system (Lillis, Simmons, Swan, \& Haar, 2008).
The aspects of prevention, self-care and support for people with diabetes mellitus have become a major concern and are very important to be developed (International Diabetes Federation, 2015). One of them is the diabetes mellitus education program which is part of the self-care management of diabete mellitus patients (International Diabetes Federation, 2015; Haas et al., 2013; Siminerio, 2008). The importance of educational programs for people with diabetes mellitus has some limitations, such as the low number of patients who received education and low adherence levels in the program (Haas et al., 2013; Siminerio et al., 2008; Cauch-Dudek et al. , 2013; Hasseler, et al., 2011).

Chronic Disease Management Program (Prolanis) is one of the National Health Insurance (JKN) programs located at the primary health care services with integrated promotive and preventive activities which aims to improve individual skills and maintain the health of chronic diseases patients (Soewondo, 2012). There are four main activities of Prolanis, which are education, counseling, participants' reminder and home 
visits (BPJS Health, 2014). Based on Health Insurance Administrating Body (BPJS) Regulation regarding Health No. 2 Year 2015, mentioned that one indicator of service commitment which should be evaluated by Primary-Level Health Care (FKTP) is the ratio of Prolanis participants who routinely visit FKTP achieves the target of at least $50 \%$ visit every month (BPJS Health, 2015).

According to a study conducted by Idris (2014), the level of participants adherence to follow Prolanis activities on a regular basis has not been optimal. Based on PT ASKES data in 2010, Prolanis program managed to capture a considerable number of participants, but not accompanied by continuity of the visits. The same thing is also reported by IDMPS which states that the annual visit of type 2 diabetes patients to Advaced-Level Health Care (FKTL) is higher than to FKTP.

Bekasi is the Regency/City in West Java Province which ranked second with the highest prevalence of type 2 diabetes in West Java which is equal to $2.7 \%$ (Balitbangkes, 2014b). Based on the recommendation of BPJS Bekasi branch, there are 5 FKTP which have run Prolanis well enough, namely Guci Medika Clinic, Jatimulya Primary Health Care (Puskesmas), Paramitra Medika Clinic, Citra Sehat Clinic, and Husada Clinic.

Based on the initial survey conducted at the five FKTP, the continuity of Prolanis participants visit with type 2 diabetes is not optimal. There has been no research on the adherence level and its determinants of attending Prolanis in participants with type 2 diabetes through the Health Belief Model approach. Hence, there should be a study which could be used as reference for improvement of the health program in the future.

\section{METHODS}

This study used cross sectional method. The population was all patients of type 2 diabetes who follow Prolanis actively at five FKTP BPJS Bekasi, with the total number of 269 participants. The sample in this study were patients with type 2 diabetes who follow Prolanis actively at five FKTP BPJS Bekasi with the inclusion criteria, i.e. have been a member of Prolanis at least 6 months, have no complication of serious disease and willing to become respondent. A sample of 207 participants was calculated using the mean estimation formula with $95 \%$ confidence level and $80 \%$ power of test. To avoid the drop out, then the number of samples added $10 \%$ and made the total amount is 228 .

The sampling technique used was a simple random sampling by allocating the sample proportionally based on the number of participants at the five FKTP. Independent variables are length of illness, knowledge, self efficacy, satisfaction of program, perceived susceptibility, perception perceived seriousness, perceived benefits, perceived barriers, physician-patient relationship, family support and implementation of program guideline; while dependent variable is adherence level of patient with level type 2 diabetes who follow the Prolanis. The data used in this study is primary data which derived from the answer of patients with type 2 diabetes who follow Prolanis through filling questionnaires.

The questionnaire used is the adaptation form of some standardized questionnaires, such as Diabetes Knowledge Questionnare to measure the variables of knowledge and Health Belief Model to measure the scale of self efficacy variables and the other four perceptions. Patient Satisfaction Questionnare was adapted for program satisfaction variables, while for physician-patient relationship variables adapted Trust in Physician Scale, and family support variables using the questionnaire from Hasbi (2012). The questionnaires had previously been tested for its validity and reliability at Ciomas Health Center in Bogor Regency which has Prolanis characteristics similar to the research location. Data were analyzed by univariate, bivariate with simple linear regression and multivariate using multiple linear regression.

\section{RESULTS AND DISCUSSIONS}

\section{Characteristics of Respondents}

The demographic characteristics of respondents in the form of categorical data in table 1 are outlined by sex and occupation. While the numerical data characteristics in table 2 are described by age and education level. Patients with type 2 diabetes who follow Prolanis at five FKTP BPJS Bekasi amounted to 68 people $(30.9 \%)$ for male and 152 people $(69.1 \%)$ for female. The number of patients with type 2 diabetes who follow the Prolanis with the status of employed (civil servants/police, laborers, traders/entrepreneurs and private employees) was fewer i.e. 53 people $(24.1 \%)$ compared with unemployed (unemployed, retired and housewife) i.e. 167 people (75.9\%). The average age of type 2 diabetes patients who follow Prolanis at five FKTP BPJS Bekasi is 57.06 years, with the lowest age is 31 years and the highest age is 76 years. Respondents with the lowest level of education were 0 years (not attending school) and the highest level of education was 19 years.

\begin{tabular}{lcc}
$\begin{array}{c}\text { Table 1. Distribution of Characteristics (Sex and Occupation) in } \\
\text { Prolanis at Five FKTP BPJS Bekasi }\end{array}$ \\
\hline Characteristics & Number & Percentage \\
\hline Sex & 68 & 30.9 \\
Male & 152 & 69.1 \\
Female & & \\
Employment & & \\
Employed & 53 & 24.1 \\
Unemployed & 167 & 75.9 \\
Total & 220 & 100 \\
\end{tabular}




\begin{tabular}{|c|c|c|c|c|c|}
\hline \multicolumn{2}{|c|}{ Variable } & \multirow{2}{*}{$\begin{array}{l}\text { Mean } \\
57.06\end{array}$} & \multirow{2}{*}{$\begin{array}{c}\begin{array}{c}\text { Standard } \\
\text { Deviation }\end{array} \\
8.048\end{array}$} & \multirow{2}{*}{$\begin{array}{c}\begin{array}{c}\text { Minimum- } \\
\text { Maximum }\end{array} \\
31-76\end{array}$} & \multirow{2}{*}{$\begin{array}{c}\mathbf{9 5} \% \mathbf{C I} \\
55.99- \\
58.13\end{array}$} \\
\hline Characteristics & Age & & & & \\
\hline & $\begin{array}{l}\text { Level of } \\
\text { education }\end{array}$ & 11.31 & 3.579 & $0-19$ & $\begin{array}{l}10.84- \\
11.79\end{array}$ \\
\hline & $\begin{array}{l}\text { Adherence } \\
\text { level at } 5 \\
\text { FKTP BPJS }\end{array}$ & 3.59 & 1.673 & $1-6$ & $3.37-3.81$ \\
\hline \multirow{4}{*}{$\begin{array}{l}\text { Adherence } \\
\text { Level of Type } \\
\text { 2 Diabetes } \\
\text { Patient } \\
\text { Following } \\
\text { Prolanis }\end{array}$} & $\begin{array}{l}\text { Adherence } \\
\text { level in }\end{array}$ & & & & \\
\hline & $\begin{array}{l}\text { Primary Health } \\
\text { Care } \\
\text { (Puskesmas) }\end{array}$ & 2.94 & 1.540 & $1-6$ & $2.39-3.49$ \\
\hline & $\begin{array}{l}\text { Adherence } \\
\text { level in four }\end{array}$ & & & & \\
\hline & Primary Clinics & 3.71 & 1.673 & $1-6$ & $3.46-3.95$ \\
\hline \multirow[t]{4}{*}{$\begin{array}{l}\text { Modifying } \\
\text { Factors }\end{array}$} & $\begin{array}{l}\text { Length of } \\
\text { illness }\end{array}$ & 77.95 & 8.719 & $6-588$ & $\begin{array}{l}67.23- \\
88.68\end{array}$ \\
\hline & Knowledge & 6.59 & 1.867 & $2-10$ & $6.34-6.83$ \\
\hline & Self Eficacy & 11.88 & 1.736 & $7-16$ & $\begin{array}{l}11.65- \\
12.11\end{array}$ \\
\hline & $\begin{array}{l}\text { Program } \\
\text { satisfaction }\end{array}$ & 13.20 & 1.636 & $8-17$ & $\begin{array}{l}12.99- \\
13.42\end{array}$ \\
\hline \multirow[t]{4}{*}{$\begin{array}{l}\text { Individual } \\
\text { Perception }\end{array}$} & $\begin{array}{l}\text { Percieved } \\
\text { Susceptibility }\end{array}$ & 5.86 & 1.087 & $2-8$ & $5.71-6$ \\
\hline & $\begin{array}{l}\text { Percieved } \\
\text { seriousness }\end{array}$ & 6.43 & 1.227 & $2-8$ & $6.27-6.59$ \\
\hline & $\begin{array}{l}\text { Percieved } \\
\text { benefits }\end{array}$ & 11.96 & 1.939 & $4-16$ & $\begin{array}{l}11.71- \\
12.22\end{array}$ \\
\hline & $\begin{array}{l}\text { Percieved } \\
\text { barriers }\end{array}$ & 17.60 & 2.859 & $8-24$ & $\begin{array}{l}16.84- \\
17.60\end{array}$ \\
\hline \multirow[t]{3}{*}{ Cue to Action } & $\begin{array}{l}\text { Doctor-patient } \\
\text { relationship }\end{array}$ & 23.88 & 2.125 & $15-31$ & $\begin{array}{l}23.60- \\
24.16\end{array}$ \\
\hline & Family support & 6.33 & 1.654 & $2-8$ & $6.11-6.55$ \\
\hline & $\begin{array}{l}\text { Implementation } \\
\text { of program } \\
\text { guideline }\end{array}$ & 5.62 & 2.297 & $1-9$ & $5.32-5.93$ \\
\hline
\end{tabular}

\section{Level of Adherence in Type 2 Diabetes Patient Following Prolanis}

The average patient adherence level of type 2 diabetes patient following Prolanis at five FKTP BPJS Bekasi is 3.59 times with variation of 1.673. The lowest adherence level is 1 time and the highest level of adherence is 6 times. From the interval estimation result, it could be concluded that $95 \%$ is believed that the average of adherence level of Prolanis participants with type 2 diabetes at five FKTP BPJS Bekasi is between 3.37 to 3.81 .

Comparing between Primary Health Care (Puskesmas) and Pratama Clinic, the level of adherence in the four Pratama Clinics is higher than Puskesmas. The adherence level in Pratama Clinic is 3.71 (95\% CI: 3.37-3.81) with variation of 1.673. The lowest adherence level is 1 time and the highest level of adherence is 6 times. While for the level of adherence in Jatimulya Primary Health Care as on of the FKTP BPJS Bekasi is 2.94 times (95\% CI: 2.39 - 3.49) with standard deviation 1,540. The lowest adherence level is 1 time and the highest level of compliance is 6 times.

\section{Modifying Factors}

The average length of illness in Prolanis participants with type 2 diabetes at five FKTP BPJS Bekasi is 77.95 months with variation of 8.719 . The lowest length of illness is 6 months and the highest is 588 months (49 years). From the estimation result, it could be concluded that $95 \%$ is believed that the average length of illness in Prolanis participants with type 2 diabetes at five FKTP BPJS Bekasi is between 67.23 months up to 88.68 months.

For the average level of knowledge score of the Prolanis participants with type 2 diabetes at five FKTP BPJS Bekasi is 6.59 with standard deviation 1.867. The lowest score is 2 and the highest score is 10 . From the result of interval estimation, it could be concluded that $95 \%$ average level of knowledge score of Prolanis participants with type 2 diabetes in five FKTP BPJS Bekasi is between 6.34 up to 6.83 .

Based on table 2, the average score for self efficacy variable of type 2 diabetes patients who follow Prolanis at five FKTP BPJS Bekasi is 11.88 with variation of 1.736 . The lowest score is 7 and the highest score is 16 . From the interval estimation result, it could be concluded that $95 \%$ is believed that the average self efficacy score on the type 2 diabetes patient following Prolanis at five FKTP BPJS Bekasi is between 11.65 to 12.11 .

For the mean score of the program satisfaction variable in patients with type 2 diabetes following Prolanis at five FKTP BPJS Bekasi is 13.20 with variation of 1.636 . The lowest score is 8 and the highest score is 17. From the interval estimation result, it could be concluded that $95 \%$ is believed that the average score of program satisfaction in patients with type 2 diabetes following Prolanis at five FKTP BPJS Bekasi id between 12.99 to 13.42.

\section{Individual Perception}

The average score for the percieved susceptibility variable in patients with type 2 diabetes who follow Prolanis at five FKTP BPJS Bekasi was 5.86 with variation of 1.087 . The lowest score is 2 and the highest score is 8 . From the interval estimation result, it could be concluded that $95 \%$ is believed that the average score of percieved susceptibility in type 2 diabetes patient following Prolanis at five FKTP BPJS Bekasi is between 5.71 up to 6 .

For the average score of percieved seriousness variables in patients with type 2 diabetes who follow Prolanis in five FKTP BPJS Bekasi is 6.43 with standard deviation of 1.227. The lowest score is 2 and the highest value is 8 . From the interval estimation result, it could be concluded that $95 \%$ is believed that the average score of percieved seriousness in patients with type 2 diabetes following Prolanis at five FKTP BPJS Bekasi branch is between 6.27 
up to 6.59 .

Based on table 2, the average score for the percieved benefits variable in patients with type 2 diabetes at five FKTP BPJS Bekasi is 11.96 with variation of 1.939 . The lowest score is 4 and the highest score is 16 . From the interval estimation result, it could be concluded that $95 \%$ is believed that the average score of perceived benefits in Prolanis participants with type 2 diabetes at five FKTP BPJS Bekasi is between 11.71 to 12.22 .

For percieved barriers variable in patients with type 2 diabetes who follow Prolanis at five FKTP BPJS Bekasi got an average score of 17.60 with a variation of 2.859 . The lowest score is 8 and the highest value is 24 . From the interval estimation result, it could be concluded that $95 \%$ is believed that the average score of percieved barriers in type 2 diabetes patient following Prolanis at five FKTP BPJS Bekasi is between 16.84 to 17.60 .

\section{Cue to Action}

The average score for the physician-patient relationship in type 2 diabetes patient who follow Prolanis at five FKTP BPJS Bekasi was 23.88 with a variation of 2.125. The lowest score is 15 and the highest score is 31 . From the interval estimation result, it could be concluded that $95 \%$ is believed that the average score of physician's relation with type 2 diabetes patient following Prolanis at five FKTP BPJS Bekasi is between 23.60 to 24.16.

For family support variable of type 2 diabtes patient who follow Prolanis at five FKTP BPJS Bekasi got average score score is 6.33 with standard deviation 1.654. The lowest score is 2 and the highest value is 8 . From the interval estimation result, it could be concluded that $95 \%$ is believed that the average score of the relation between physician with type 2 diabetes patient following Prolanis at five FKTP BPJS Bekasi is between 6.11 to 6.55.

The average score for program implementation guideline variable in patients with type 2 diabetes who follow Prolanis at five FKTP BPJS Bekasi is 5.62 with a variation of 5.93. The lowest score is 1 and the highest value is 9 . From the interval estimation result, it could be concluded that $95 \%$ is believed that the average score of the program implementation guideline in the type 2 diabetes patient following Prolanis at five FKTP BPJS Bekasi is between 5.32 up to 5.93 .

Table 3 Correlation and Regression Analysis of Each Independent Variable with Adherence Level of Type 2 Diabetes Patients Following Prolanis at Five FKTP BPJS Bekasi

\begin{tabular}{lcccc}
\hline \multicolumn{1}{c}{ Variable } & $\boldsymbol{r}$ & $\mathbf{R}^{\mathbf{2}}$ & Equation of Line & -value \\
\hline $\begin{array}{l}\text { Length of } \\
\text { illness }\end{array}$ & 0.098 & 0.010 & $\begin{array}{c}\text { Adherence level }=3.432+0.002^{*} \\
\text { Length of illness }\end{array}$ & 0.146 \\
Knowledge & 0.174 & 0.030 & $\begin{array}{c}\text { Adherence level }=2.566+0.156^{*} \\
\text { Knowledge }\end{array}$ & 0.01 \\
Sefl eficacy & 0.041 & 0.002 & $\begin{array}{c}\text { Adherence level }=3.124+0.039^{*} \\
\text { Sefl eficacy }\end{array}$ & 0.547 \\
$\begin{array}{l}\text { Program } \\
\text { satisfaction }\end{array}$ & 0.138 & 0.019 & $\begin{array}{c}\text { Adherence level }=1.733+0.141^{*} \\
\text { Program satisfaction }\end{array}$ & 0.042 \\
\hline
\end{tabular}

\begin{tabular}{lccccc}
$\begin{array}{l}\text { Percieved } \\
\text { susceptibility }\end{array}$ & 0.054 & 0.003 & $\begin{array}{l}\text { Adherence level }=4.082-0.084^{*} \\
\text { Percieved susceptibility }\end{array}$ & 0.422 \\
$\begin{array}{l}\text { Percieved } \\
\text { seriousness }\end{array}$ & 0.120 & 0.014 & $\begin{array}{c}\text { Adherence level }=2.541+0.163^{*} \\
\text { Percieved seriousness }\end{array}$ & 0.076 \\
$\begin{array}{l}\text { Percieved } \\
\text { benefits }\end{array}$ & 0.427 & 0.183 & $\begin{array}{c}\text { Adherence level }=-0.820 \\
+0.369 * \text { Percieved benefits }\end{array}$ & 0.0005 \\
$\begin{array}{l}\text { Percieved } \\
\text { barriers }\end{array}$ & 0.707 & 0.500 & $\begin{array}{c}\text { Adherence level }=10.714- \\
0.414^{*} \text { Percieved barriers }\end{array}$ & 0.0005 \\
$\begin{array}{l}\text { Physician- } \\
\text { patient } \\
\text { relationship }\end{array}$ & 0.129 & 0.017 & $\begin{array}{c}\text { Adherence level }=1.167+0.101^{*} \\
\text { Physician-patient relationship }\end{array}$ & 0.056 \\
$\begin{array}{l}\text { Familty } \\
\text { support }\end{array}$ & 0.1 & 0.01 & $\begin{array}{c}\text { Adherence level }=2.947+0.102^{*} \\
\text { Familty support }\end{array}$ & 0.138 \\
$\begin{array}{l}\text { Implementation } \\
\text { of program } \\
\text { guideline }\end{array}$ & 0.324 & 0.105 & $\begin{array}{c}\text { Adherence level }=2.262+0.236^{*} \\
\text { Program mplementation } \\
\text { guideline }\end{array}$ & 0.0005 \\
\hline
\end{tabular}

Based on the result of bivariate analysis above, there are several variables which correlated significantly with adherence level of type 2 diabetes patient following Prolanis ( $p$-value $<0.05$ ), namely knowledge, program satisfaction, percieved benefits, percieved barriers, physician-patient relationship and program guideline implementation.

The relationship between knowledge and adherence level of type 2 diabetes patient following Prolanis at five FKTP BPJS Bekasi

The relationship between knowledge with adherence level of type 2 diabetes patient following Prolanis at five FKTP BPJS Bekasi shows a weak relationship $(r=0.174)$ and a positive pattern means that the increasing knowledge of Prolanis participants with type 2 diabetes will be higher the level of adherence. The coefficient of determination 0.03 means that the equation of regression line obtained could only explain 3\% variation of adherence level; or in other words, the line equation obtained is not good enough in explaining the adherence level variable in Prolanis participants with type 2 diabetes at five FKTP BPJS Bekasi. The test results obtained by regression line equation $\mathrm{Y}=2.566+0.156 \mathrm{X}$ to predict the adherence level variable of Prolanis participants with type 2 diabetes based on the knowledge variables.

Knowledge is important in supporting the participants' adherence level of diabetes education program. Good knowledge of diabetes mellitus disease is associated with good self-care management as well, including participating in dianetes education programs (Haas et al., 2012; Ramal et al., 2012; Adejoh, 2014). The relationship between knowledge and adherence with the health education program also takes place in two directions, where good adherence to follow the education program could increase participants' knowledge of the disease and selfmanagement of diabetes mellitus.

The relationship between program satisfaction and patient adherence level of type 2 diabetes patient following Prolanis at five FKTP BPJS Bekasi 
The relationship between the satisfaction of the program and the adherence level of the type 2 diabetes patients who follow Prolanis at five FKTP BPJS Bekasi shows a weak relationship $(r=0.138)$ and the positive pattern means that the more program satisfaction in Prolanis participants with type 2 diabetes, the higher adherence level. The coefficient of determination 0,019 means that the equation of regression line obtained could only explain $1.9 \%$ variation of adherence level; or in other words, the line equation obtained is not good enough in explaining the variable of adherence level in patients with type 2 diabetes following Prolanis at five FKTP BPJS Bekasi. The statistical test results obtained by regression line equation $\mathrm{Y}=1.733+$ $0.141 \mathrm{X}$ to predict adherence level of type 2 diabetes patients who follow Prolanis based on the variable of program satisfaction.

This result is in accordance with a cohort study conducted by Meisenhelder-Smith (2006) in 159 people with type 2 diabetes in the Tampa Bay, Florida, USA indicating that there is a relationship between the participants' satisfaction of diabetes mellitus education and adherence to the program. Satisfaction with the program leads to compliance because based on the assessment given by the respondents on the questionnaire, it could be concluded that the choice of "very good" and "good" answers to the Prolanis implementation which includes the overall quality of Prolanis, the methods used, the facilities and infrastructure used, are the highest compared to the proportion of "ordinary" and "bad" answers (table 3). Hence, the more satisfaction of the program in patients with type 2 diabetes who follow Prolanis would make higher level of adherence.

\section{The relationship between perceived benefits to the level of adherence of type 2 diabetes patients who follow Prolanis at five FKTP BPJS Bekasi}

The relationship between perceived benefits and patient adherence level of type 2 diabetes following Prolanis at five FKTP BPJS Bekasi shows moderate relationship ( $\mathrm{r}=$ 0.427) and positive pattern means that increasing percieved benefits to Prolanis participants with type 2 diabetes would make a higher level of compliance. Obtained coefficient of determination of 0.183 means that the regression line equation obtained could explain $18.3 \%$ variation of adherence level; or in other words, the line equation obtained is good enough to explain the variable of adherence level in patients with type 2 diabetes following Prolanis at five FKTP BPJS Bekasi. Statistical test results obtained by regression line equation $\mathrm{Y}=-0.82$ $+0.369 \mathrm{X}$ to predict adherence level variable of type 2 diabetes patients who follow Prolanis based on perceived benefits variable.

Perceived benefit is a factor associated with self-care diabetes mellitus patients. Level of trust in the effectiveness of therapy is a good predictor of selfmanagement in diabetes mellitus disease compared to inhibiting factors or percieved seriousness (Adejoh, 2014). Increasing the percieved benefits and decreasing perceived barriers are important to increase participants' participation in diabetes mellitus education programs (Jalilian, Motlagh, Solhi, \& Gharibnavaz, 2014). The percieved benefits and barriers to a person is good enough to explain the level of adherence to the diabetes mellitus education program by $43 \%$ (Adejoh, 2014).

\section{Relationship between percieved barriers to patient adherence level of type 2 diabetes following Prolanis at five FKTP BPJS Bekasi}

The relationship between percieved barriers and patient adherence level of type 2 diabetes following Prolanis at five FKTP BPJS Bekasi shows strong relation $(r=0.707)$ and patterned negatively means the increasing percieved barriers of type 2 diabetes patient following Prolanis will lower the level of adherence. The coefficient of determination value of 0,5 means that the equation of regression line obtained could explain $50 \%$ variation of adherence level; or in other words, the line equation obtained is good enough in explaining the variable of adherence level in patients with type 2 diabetes following Prolanis at five FKTP BPJS Bekasi. Statistical test results obtained by regression line equation $\mathrm{Y}=10.714-0.414 \mathrm{X}$ to predict adherence level variable of Prolanis participants with type 2 diabetes based on perceived barriers variable.

Of all the concepts of individual perception in the Health Belief Model, the concept of perceived barriers is highly correlated and the strongest predictor in determining individual behavior (Bayat et al., 2013; Glanz et al., 2008; Meisenhelder-Smith, 2006). Based on the description of the respondents' answer to the question of the barriers variable in the questionnaire, mentioned that the highest proportion of participants in following Prolanis are forgot the Prolanis schedule $(33.6 \%)$, family problem $(30.9 \%)$, unmatched Prolanis schedule with participants' activities $(25 \%)$ and busy or did not have time to follow Prolanis activities regularly (18\%).

\section{Physician-patient relationship to patient adherence level of type 2 diabetes following Prolanis at five FKTP BPJS Bekasi}

The correlation between physician-patient relationship with patient adherence level of type 2 diabetes following Prolanis at five FKTP BPJS Bekasi shows weak relationship $(\mathrm{r}=0.129)$ and patterned positive. The coefficient of determination 0,017 means that the equation of regression line obtained could only explain $1.7 \%$ variation of adherence level; or in other words, the line equation obtained is not good enough in explaining the variable of adherence level in patients with type 2 diabetes following Prolanis at five FKTP BPJS Bekasi. Statistical test results obtained by the equation of the line $\mathrm{Y}=1.167+$ $0.101 \mathrm{X}$ to predict the dependent variable of adherence level in type 2 diabetes patient following Prolanis.

This result is in line with previous studies stating that there is a correlation between physician-patient relationship with adherence to diabetes mellitus education program (Ha \& Longnecker, 2010; Irwin M. Rosenstock, 1985; Lee, 2007). 
The proportion of participants who answered "agree" to positive statements regarding the physician-patient relationship is quite large. This might be due to good relationship and communication between patient and physician, even though there is no diabetes mellitus education program such as Prolanis. This is because the relationship between physicians and patients has been known to play an important role in the medical treatment process and the success of healing.

The relationship between the implementation of program guideline and the adherence level of type 2 diabetes patients who follow Prolanis at five FKTP BPJS Bekasi

The relationship between the implementation of the program guidelines and the adherence level of patients with type 2 diabetes who follow Prolanis at five FKTP BPJS Bekasi shows moderate relationship $(r=0.324)$ and positive pattern means that the implementation of program guideline for type 2 diabetes patients following Prolanis would make higher adherence. The coefficient of determination obtained of 0.105 means that the regression line equation obtained could only explain $1.05 \%$ variation of adherence level; or in other words, the line equation obtained is not good enough in explaining the level of compliance variable in patients with type 2 diabetes following Prolanis at five FKTP BPJS Bekasi. Statistical test results obtained by regression line equation $\mathrm{Y}=2.262$ $+0.236 \mathrm{X}$ to predict adherence level of type 2 diabetes patients who follow Prolanis based on program guideline implementation variable.

The success of a diabetes mellitus education program is centered on health care facility's role in facilitating the needs and conditions of its participants. Therefore, it is necessary to have a good system by taking into account the short-term and long-term objectives of the program, so that the expected impacts on improving the health status of participants and public health could generally be achieved (Lee, 2007). In FKTP where the program activities are conducted in accordance with the existing guidelines, shows the better participants' adherence level than other FKTP who do not run the program in accordance with the BPJS Health recommendation. This is in line with the results of the analysis in the table above which states that the higher value for the implementation of program guidelines, the higher level of adherence in Prolanis participants with type 2 diabetes.

\section{Multivariate Analysis}

In multivariate analysis, this paper used multiple linear regression method which consists of bivariate selection and modeling. Based on the result of bivariate selection, there are 9 variables which could proceed to multivariate modeling because it has $\mathrm{p}$-value $<0.25$. While the other 2 variables, self efficacy and percieved susceptibility variables, could not proceed to multivariate modeling. The results obtained last modeling is as follows:

\begin{tabular}{lccccc}
\multicolumn{5}{c}{ Table 4. Multivariate Last Modeling } \\
\hline \multicolumn{1}{c}{ Variable } & $\begin{array}{c}\boldsymbol{p} \\
\text { value }\end{array}$ & $\begin{array}{c}\text { B } \\
\text { Coefficient }\end{array}$ & $\boldsymbol{r}$ & $\mathbf{R}^{2}$ & $\begin{array}{r}\boldsymbol{p} \text { value } \\
\text { Model }\end{array}$ \\
\hline Length of illness & & & 0.763 & 0.582 & 0.0005 \\
Percieved benefits & 0.047 & 0.002 & & & \\
$\begin{array}{l}\text { Percieved } \\
\text { barrierss }\end{array}$ & 0.0005 & 0.219 & & \\
$\begin{array}{l}\text { Program } \\
\text { guideline } \\
\text { implementation }\end{array}$ & 0.0005 & -0.359 & & \\
$\begin{array}{l}\text { Family support } \\
\text { Knowledge }\end{array}$ & 0.002 & 0.111 & & \\
$\begin{array}{l}\text { Program } \\
\text { satisfaction }\end{array}$ & 0.421 & 0.037 & \\
$\begin{array}{l}\text { Percieved } \\
\text { seriousness }\end{array}$ & 0.243 & -0.059 & \\
$\begin{array}{l}\text { Physician-patient } \\
\text { relationship }\end{array}$ & 0.168 & -0.106 & \\
\hline & & -0.074 & \\
\hline
\end{tabular}

Based on the table above, there are four variables which correlate significantly with the adherence level of Prolanis participants with type 2 diabetes, namely length of illness, percieved benefits, perceived barriers and implementation of program guidelines. While the other five independent variables remain included in the modeling as confounding because if it released, it would cause the change $B$ coefficient $>10 \%$. Then, conducted the assumption test of the model and after analyzed, the result of all assumptions are fulfilled. Afterwards, conducted interaction test on variables which are substantially suspected to have interaction, namely the percieved benefits and perceived barriers. The results are as follows:

Table 5 Multivariate Last Modeling with Interaction

\begin{tabular}{|c|c|c|c|c|c|c|}
\hline Variabel & p-value & $\begin{array}{c}\text { B } \\
\text { Coefficient }\end{array}$ & $\begin{array}{c}\beta \\
\text { Coefficient }\end{array}$ & $\mathbf{R}$ & $\mathbf{R}^{2}$ & $\begin{array}{l}p \text {-value } \\
\text { Model }\end{array}$ \\
\hline Length of illness & 0.051 & 0.002 & 0.087 & 0.784 & 0.615 & 0.0005 \\
\hline $\begin{array}{l}\text { Percieved } \\
\text { benefits }\end{array}$ & 0.003 & -0.610 & -0.707 & & & \\
\hline Percieved & 0.0005 & -0.998 & -1.705 & & & \\
\hline barrierss & 0.006 & 0.095 & 0.131 & & & \\
\hline $\begin{array}{l}\text { Program } \\
\text { guideline } \\
\text { implementation }\end{array}$ & 0.848 & 0.009 & 0.009 & & & \\
\hline Family support & 0.336 & 0.043 & 0.048 & & & \\
\hline Knowledge & 0.697 & -0.019 & -0019 & & & \\
\hline $\begin{array}{l}\text { Program } \\
\text { satisfaction }\end{array}$ & 0.169 & -0.102 & -0.075 & & & \\
\hline $\begin{array}{l}\text { Percieved } \\
\text { seriousness }\end{array}$ & 0.191 & -0.053 & -0.067 & & & \\
\hline $\begin{array}{l}\text { Physician- } \\
\text { patient } \\
\text { relationship }\end{array}$ & 0.0005 & 0.052 & 1.148 & & & \\
\hline $\begin{array}{l}\text { Percieved } \\
\text { benefits by } \\
\text { perceived } \\
\text { barrierss }\end{array}$ & & & & & & \\
\hline
\end{tabular}


Based on the table above, shows that the interaction test between the variables of perceived benefits and perceived barriers has a significant value which is $0.0005 \mathrm{p}$-value, so there is interaction between the percieved benefits and barriers which included in the model. The value of R2 becomes 0.615 , meaning the ability of these variables in explaining the compliance level of type 2 diabetes patients who follow Prolanis at five FKTP BPJS Bekasi is quite good, which is equal to $61.5 \%$. Then the result of p-value model is 0.0005 , so the tenth variables could significantly predict the compliance level of type 2 diabetes patient following Prolanis. From the last modeling, it is seen that the biggest variable influence on the adherence level of type 2 diabetes patients following Prolanis is perceived barriers (beta coefficient $=-1.705$ ).

The last multivariate modeling with much confounding as in this study could occur because based on the Health Belief Model, the four main perceptions could be influenced by other variables: modifying variables which include knowledge, program satisfaction and self efficacy. Modifying variables are the characteristics of the individual which could affect a person's perception. Likewise with cue to action which is a factor that encourages or stimulates the occurrence of a behavior in a person. In this study, cue to action which became confounder are physician-patient relationship and family support variables. So in other words, a person's behavior is determined by four major perceptions and influenced by modifying variables and cue to action (Glanz et al., 2008; Irwin, 1985). Therefore, the nine variables are simultaneously affect the adherence level of patients with type 2 diabetes who follow Prolanis at five FKTP BPJS Bekasi.

The interaction test shows that between perceived benefits and barriers causing heterogeneity effect on adherence level of type 2 diabetes patients following Prolanis. Perceived benefits and barriers are two major perceptions in the Health Belief Model that determine a person to act on his illness (likelihood of action) (Irwin, 1985). The model explains that a person has a tendency to abide by doctors' recommendations if they believe that the therapy is beneficial to his health (Glanz et al., 2008). The benefits are believed to be greater than the disadvantages of a program, so it is mentioned that the two concepts are the most significant in determining a person's behavior change (Meisenhelder, 2006).

Increasing the percieved benefits and decreasing percieved barriers is important to increase participation in diabetes mellitus education programs (Jalilian et al., 2014). Based on a cross-sectional study conducted by Adejoh et al (2014) in 152 diabetes mellitus patients in Igala, it was mentioned that percieved benefit and barriers accounted for $43 \%$ of participants' compliance in health education programs.

Percieved barriers is the dominant factor in this study, because this perception is a person's evaluation of the barriers to perform the recommended new behavior. Of all the concepts of individual perception in the Health Belief Model, the concept of perceived barriers is highly correlated and the strongest predictor of individual behavior (Glanz et al., 2008; Meisenhelder, 2006; Bayat et al., 2013). It is important to identify the factors which prevent the participants from regular visits to diabetes mellitus education programs, so that the purpose of the program could be achieved. The perceived barriers in this study are divided into two: the perception of psychological barriers and the perception of structural barriers.

Based on the analysis, the perception of psychological barriers in this study is the lack of participants' motivation in following Prolanis (8.2\%) and participants who do not understand the benefits of Prolanis (13.6\%). For the perception of structural barriers in patients with type 2 diabetes following Prolanis, i.e. forget the Prolanis schedule $(33.6 \%)$, family problems $(30.9 \%)$, Prolanis activity schedule not fit the participant's schedule $(25 \%)$ and busy or do not have the time to follow Prolanis activities regularly (18\%)

\section{CONCLUSIONS}

From various results of data analysis and discussions of the findings in research, it could be made conclusiona as follows:

1. The adherence level of Prolanis participants with type 2 diabetes at five FKTP BPJS Bekasi is 3.59 out of 6 times, where the adherence level in Governmental FKTP (Jatimulya Primary Health Care) is 2.94 times whereas in four Pratama Clinics is 3.71 times.

2. Variables which are significantly related to the adherence level of Prolanis participants with type 2 diabetes at five FKTP BPJS Bekasi are length of illness, pecieved benefits, perceived barriers and implementation of program guidelines. Other variables i.e. knowledge, satisfaction of program, percieved seriousness, physician-patient relationship and family support become confounding variables.

3. The most dominant factor related to the adherence level in Prolanis participants with type 2 diabetes at five FKTP BPJS Bekasi is percieved barriers (Beta Coefficient $=-1.705)$.

4. There is an interaction between the percieved benefits and barriers variables significantly associated with the adherence level of Prolanis participants with type 2 diabetes, so as improving the ability of variables in the model to predict the adherence level of Prolanis participants with type 2 diabetes.

Based on the results and research conclusions, there are several things which need to be used as suggestions for program improvement futher, which are:

\section{For related institutions}

\section{a. BPJS Health Bekasi branch}

i. Improve monitoring and evaluation of the Prolanis implementation in FKTP BPJS to ensure the implementation is in accordance with existing guidelines. 
ii. Disseminate the concept of Prolanis as a health education program to both FKTP which have already and not yet run Prolanis.

iii. Improve education and training for physicians at FKTP related to chronic diseases and management of chronic diseases.

\section{b. Primary-Level Health Care (FKTP) BPJS Health}

i. Conduct education and counseling to participants regarding the prognosis of diabetes mellitus and low blood glucose levels.

ii. Find out what are the obstacles for participants to follow Prolanis regularly and how to overcome them.

iii. Increase the socialization of the Prolanis benefits to the participants and carry out 4 main activities routinely of Prolanis program, which are education, counseling, reminder and home visit.

- It is hoped that physician at FKTP could have the right knowledge and framework of thinking related to the implementation of Prolanis.

- Involve family in educational process, so that the family understans and have similar knowledge with the participants.

2. For science development

Reviewing the variables of program guidelines implementation in subsequent researches.

3. For other researchers

For further research it is necessary to investigate the benefits of Prolanis by comparing the perceptions before and after following Prolanis. It is then necessary to compare the results of clinical outcomes to participants between FKTP who have implemented program guidelines and those who do not. In addition, it is also necessary to find the determinants of adherence provider in carrying out the implementation of program guidelines.

\section{REFERENCES}

Adejoh, S. O. (2014). Diabetes Knowledge, Health Belief, and Diabetes Management Among the Igala, Nigeria. SAGE Open, 4(2). Diakses 7.01.2016

Balitbangkes. (2014b). Indeks Pembangunan Kesehatan Masyarakat 2013. Jakarta http://www.balitbangkes.go.id . Diakses 17.6.2015

Bayat, F., Shojaeezadeh, D., Baikpour, M., Heshmat, R., Baikpour, M., \& Hosseini, M. (2013). The effects of education based on extended health belief model in type 2 diabetic patients: a randomized controlled trial. Journal of Diabetes \& Metabolic Disorders, 12, 1-6. Diakses 8.01.2016.

BPJS Kesehatan. (2014). Panduan Praktis PROLANIS (Program Pengelolaan Penyakit Kronis). Jakarta.

BPJS Kesehatan. (2015). Peraturan BPJS Kesehatan No.02 Tahun 2015. www.bpjs-kesehatan.go.id/bpjs/index.php/arsip/detail/375. Diakses 20.1.2016

Cauch-Dudek, K., Victor, J. C., Sigmond, M., \& Shah, B. R. (2013). Disparities in attendance at diabetes self-management education programs after diagnosis in Ontario, Canada: a cohort study. BMC Public Health, 13(1), 1-6. doi: 10.1186/1471-2458-13-85. Diakses 8.12.2015
Garcia, A. A., Villagomez, E. T., Brown, S. A., Kouzekanani, K., \& Hanis, C. L. (2001). The Starr County Diabetes Education Study: Development of the Spanish-language diabetes knowledge questionnaire. Diabetes Care, 24(1), 16-21. Diakses 14.12.2015

Glanz, K., Rimer, B. K., \& Viswanath, K. (2008). Health Behaviour and Health Education Theory, Research, and Practice K. Glanz, B. K. Rimer, \& K. Viswanath (Eds.). Diakses 31.01.2016.

Ha, J. F., \& Longnecker, N. (2010). Doctor-Patient Communication: A Review. The Ochsner Journal, 10(1), 38-43. doi: 10.1043/TOJ-090040.1. Diakses 31.01.2016

Haas et al (2013). National Standards for Diabetes Self-Management Education and Support. Diabetes Care, 36, S100-108. doi: 10.1002/14651858.CD004015.pub3. Diakses 14.12.2015.

Hasbi, Muhammad. (2012). Analisis Faktor yang Berhubungan dengan Kepatuhan Penderita DM dalam Melakukan OLahraga di Wilayah Kerja Puskesmas Praya Lombok Tengah. Tesis. Depok. Fakultas Ilmu Keperawatan.

Hasseler, M. K., von der Heide, M., \& Indefrey, S. (2011). Resources for and barrierss to effective diabetes care management--experiences and perspectives of people with type 2 diabetes. Journal of Public Health, 19(1), 65-71. doi: http://dx.doi.org/10.1007/s10389-0100354-6. Diakses 30.9.2015

Idris, Fachmi. (2014). Pengintegrasian Program Preventif Penyakit Diabetes Melitus Tipe 2 PT Askes (Persero) ke Badan Penyelenggara Jaminan Sosial Kesehatan (BPJS Kesehatan). J Indon Med Assoc, Volum: 64, Nomor: 3, Maret 2014 p.115-121. eprints.unsri.ac.id/5313/. Diakses 4.5.2015

International Diabetes Federation. (2015). Diabetes Atlas. 7th ed.: International Diabetes Federation. http://www.idf.org/sites/default/files/EN_6E_Atlas_Full_0.pdf. Diakses 6.2.2016.

Irwin M.Rosenstock, P. (1985). Understanding and Enhancing Patient Compliance with Diabetic Regimens. Diabetes Care, vol. 8 no. 6 610-616. doi: doi: 10.2337/diacare.8.6.610. Diakses 16.2.2016

Jalilian, F., Motlagh, F., Solhi, M., \& Gharibnavaz, H. (2014). Effectiveness of self-management promotion educational program among diabetic patients based on health belief model. Journal of Education and Health Promotion, 3, 14. doi: http://dx.doi.org/10.4103/2277-9531.127580. Diakses 06.02.2016

Lee, C. (2007). Provider participation, patient enrollment and attrition in a national diabetes disease management program in Taiwan: Determinants and policy implications. (3240756 Ph.D.), The Johns Hopkins University, Ann Arbor. Retrieved from http://search.proquest.com/docview/304860907?accountid=17242 ProQuest Dissertations \& Theses Global; ProQuest Health Management database. Diakses 12.01.2016.

Meisenhelder-Smith, J. (2006). The effects of American Diabetes Association (ADA) diabetes self-management education and continuous glucose monitoring on diabetes health beliefs, behaviors and metabolic control. (3248292 Ph.D.), University of South Florida, Ann Arbor. Retrieved from http://search.proquest.com/docview/305274027?accountid=17242 ProQuest Dissertations \& Theses Global database. Diakses 8.12.2015

Ramal, E., Petersen, A. B., Ingram, K. M., \& Champlin, A. M. (2012). Factors that Influence Diabetes Self-Management in Hispanics Living in Low Socioeconomic Neighborhoods in San Bernardino, California. Journal of Immigrant and Minority Health, 14(6), 1090-1096. doi: http://dx.doi.org/10.1007/s10903-012-9601y. Diakses 14.12.2015

Siminerio, L. M., Ruppert, K., Emerson, S., Solano, F. X., \& Piatt, G. A. (2008). Delivering Diabetes Self-Management Education (DSME) in Primary Care: The Pittsburgh Regional Initiative For Diabetes Education (PRIDE). Disease Management \& Health Outcomes, 16(4), 267-272.Diakses 14.12.2015

Soewondo, Pradana. (2012). Collaborative Role of Health Practitioners in Diabetes Mellitus Management. Jakarta. www.farmasi.ui.ac.id/.../L2-Prof-Pradana. Diakses 4.5.2015 